\title{
Effects of Yeast on the Growth Performance of Sangkuriang Catfish Fingerlings (Clarias gariepinus var. Sangkuriang)
}

\author{
Diana Rachmawati ${ }^{1 *}$, Sarjito ${ }^{1}$, Istiyanto Samidjan ${ }^{1}$, Dewi Nurhayati ${ }^{1}$ and Putut \\ Har Riyadi
}

${ }^{1}$ Department of Aquaculture, Faculty of Fisheries and Marine Sciences, Diponegoro University, Semarang, 1269, Central Java, Indonesia

${ }^{2}$ Department of Fisheries Product Technology, Faculty of Fisheries and Marine Sciences, Diponegoro University, Semarang 50275, Central Java, Indonesia

\begin{abstract}
The success of the intensive culture of Sangkuriang catfish (Clarias gariepinus var. Sangkuriang) highly depends on the availability of feed. The feed is the most significant share of cost production hamper (50-60\%). Therefore, it is suggested that feed utilization is inefficient. One of the solutions is to enrich the commercial feed with yeast (Saccharomyces cerevisiae). The research aimed to identify the impacts of yeast (S. cerevisiae) enhanced feed on feed efficiency, growth, and survival rate of Sangkuriang catfish fingerlings. The treatments research was yeast $(S$. cerevisiae) enrichment in the commercial feed at the various dosages: $0 \% / \mathrm{kg}$ feed (A), $3 \% / \mathrm{kg}$ feed (B), $6 \% / \mathrm{kg}$ feed (C), $9 \% / \mathrm{kg}$ feed (D), and $12 \% / \mathrm{kg}$ feed (E). The yeast (S. cerevisiae) enrichment in the commercial feed increased feed efficiency and survival rate of Sangkuriang catfish fingerlings.

ARTICLE INFO

Article history:

Received: 11 October 2021

Accepted: 8 December 2021

Published: 10 February 2022

DOI: https://doi.org/10.47836/pjtas.45.1.16

E-mail addresses:

dianarachmawati1964@gmail.com (Diana Rachmawati)

The optimum dosage of $S$. cerevisiae for apparent digestibility coefficients for protein (ADCp), efficiency feed utilization (EFU), protein efficiency ratio (PER), and relative growth rate (RGR) ranged from $6.10 \%$ to $6.51 \% / \mathrm{kg}$ feed.
\end{abstract}

sarjito_msdp@yahoo.com (Sarjito)

istiyanto_samidjan@yahoo.com (Istiyanto Samidjan)

dewinurhayati24@gmail.com (Dewi Nurhayati)

putut.riyadi@live.undip.ac.id (Putut Har Riyadi)

*Corresponding author
Keywords: Aquaculture, catfish, cost, feed, growth performance, yeast 


\section{INTRODUCTION}

The success of the intensive culture of Sangkuriang catfish (Clarias gariepinus var. Sangkuriang) is highly related to feeding availability. Intensive aquaculture feed is the most significant share of cost production, around 50-60\% (Rachmawati \& Samidjan, 2018). Due to the inefficiency of feed to support growth, the enrichment of the commercial feed with yeast (Saccharomyces cerevisiae) is urgently needed. The yeast ( $S$. cerevisiae) could boost digestive enzyme activities; therefore, it increased the breakdown of complex nutrients into simpler forms to be easily absorbed in the digestive tract (de Azevedo et al., 2016). Sitohang et al. (2012) stated that $S$. cerevisiae produced metabolic products, including amylase and peptidase proteolytic. Protease enzymes could hydrolyze protein into peptides and amino acids. In addition, $S$. cerevisiae produced cellulase enzyme that could break down cellulose into glucose; in turn, it decreased raw fiber and the decrease of raw fiber related to the increase of carbohydrate. Manurung and Mose (2018) disclosed that yeast ( $S$. cerevisiae) could increase fish appetite by allowing catfish to feed intensively and increasing catfish growth.

Some studies on the effect yeast $(S$. cerevisiae) on freshwater and marine fish have been done, such as in Barbonymus gonionotus (Rachmawati et al., 2019a), Cyprinus carpio (Al-Refaiee et al., 2016), Oreochromis niloticus (de Azevedo et al., 2016), Pangasius hypothalamus (Rachmawati et al., 2019b), Labeo rohita
(Tewary \& Patra, 2011), and Sarotherodon galileaus (Abdel-Tawwab et al., 2010). However, there is a lack of information about the effect of yeast (S. cerevisiae) to enhance commercial feed by increasing feed efficiency and growth of Sangkuriang catfish fingerlings. The present study was to identify the impacts of yeast ( $S$. cerevisiae) enhancing feed efficiency, growth, and survival rate of Sangkuriang catfish fingerlings (Clarias gariepinus var. Sangkuriang).

\section{MATERIALS AND METHODS}

\section{Research Design}

The study used a completely randomized design with five groups, and each treatment had three replications. The research was conducted in the Sido Makmur Catfish Farmers Association, which partnered with the researchers on May-July 2020. As many as 500 test fish used in the study were catfish fingerlings with a weight of $1.12 \pm 0.36 \mathrm{~g} / \mathrm{fish}$. The catfish was obtained from the Sido Makmur Catfish Farmers Association. Sangkuriang catfish fingerlings were adapted on feed and the environment in the fiber containers in $1.5 \times 1 \times 1.5 \mathrm{~m}^{3}$ of diameter for seven days. During adaptation, the fish was fed without $S$. cerevisiae in commercial feed. After the fish had adapted, one-day fasting was introduced to neutralize metabolic residual, not affecting the initial weight. Sangkuriang catfish fingerlings were selected based on several criteria: diseasefree, malformation-free, healthy, energetic, and uniform size (Rachmawati et al., 2017). 


\section{Experimental Feed}

Test study used experimental feed, which contains $30 \%$ protein, $0.5 \%$ chromium oxide $\left(\mathrm{Cr}_{2} \mathrm{O}_{3}\right)$, and five dosages of yeast (Saccharomyces cerevisiae) treatment: A ( $0 \% / \mathrm{kg}$ feed), B (3\%/kg feed), C (6\%/kg feed), D ( $9 \% / \mathrm{kg}$ feed) and E (12\%/kg feed). Saccharomyces cerevisiae was purchased at the bread store. Commercial feed was first finely ground and mixed evenly with $0.5 \%$ $\mathrm{Cr}_{2} \mathrm{O}_{3}$. The mixture was formed as pellets with a $2 \mathrm{~mm}$ diameter, adjusted to the mouth size of the catfish fingerlings, and then dried at room temperature. Next, $S$. cerevisiae was diluted in $100 \mathrm{ml}$ water for $1 \mathrm{~kg}$ feed (de Azevedo et al., 2016). Saccharomyces cerevisiae suspension was put in the sprayer bottle and then sprayed on an experimental feed containing $\mathrm{Cr}_{2} \mathrm{O}_{3}$. After mixing, the mixture was preserved at room temperature and packed in labeled plastic bags. Then it was stored in the refrigerator until further use (Vendrell et al., 2008). Experimental feed was $5 \% /$ biomass weight/day for 63 days. Fish growth was identified by weighing the fish weekly. Fifteen plastic fiber containers were used in the research with $1 \times 1 \times 1 \mathrm{~m}^{3}$. Every treatment used three containers, equipped with a water circulation system and stocked with 50 Sangkuriang catfish fingerlings.

\section{Analysis of Protein Digestion}

The feeding at satiation was given twice a day, in the morning and afternoon. The feces were collected twice a day after being fed by siphoning the containers. First, the feces were collected in the plankton clothe net. The collected feces were then dried in the oven at $105^{\circ} \mathrm{C}$ until constant weight. After the feces had dried, it was finely ground and stored at $4{ }^{\circ} \mathrm{C}$ until analyzed. Analyses for $\mathrm{Cr}_{2} \mathrm{O}_{3}$ content in the feed and feces were based on Association of Official Analytical Chemists (AOAC) (2005) using atomic absorption spectrometer.

\section{Proximate Analysis}

Proximate analysis of the feed and the fish body at the initial and final research was based AOAC (2005) method.

Moisture. Moisture was measured by $2 \mathrm{~g}$ of the samples in the oven at $105^{\circ} \mathrm{C}$ for 24 hours. Percentage of moisture was calculated using the following formula:

$$
\mathrm{Ka}(\%)=\frac{\mathrm{W}_{1}-\mathrm{W}_{2}}{\mathrm{~W}_{1}} \times 100 \%
$$

$\mathrm{Ka}=$ Percentage of moisture (wet weight)

$\mathrm{W}_{1}=$ Weight of the sample $(\mathrm{g})$

$\mathrm{W}_{2}=$ Weight of the dried sample $(\mathrm{g})$

Crude Protein. The crude protein content was determined using the micro-Kjeldahl method. Samples ( $2 \mathrm{~g}$ ) were digested in the digestion unit for 45 minutes. The digester was then distilled in a distillation unit (Khjeltdahl System, VELP Scientifica Srl, Italy). It was titrated with $0.2 \mathrm{~N}$ hydrochloric acid (HCL), and crude protein was obtained by multiplying the total nitrogen by a conversion factor of 6.25 . 


$$
\text { Crude protein }(\%)=\frac{\text { ml titration }(\text { blank }- \text { sample }) \times \mathrm{N} \times 14,007 \times 6.25 \times 100 \%}{\text { Weight of the sample }(\mathrm{g}) \times 1000}
$$

Crude Lipid. The content of crude lipid was analyzed using the Soxhlet extraction method. Samples with known constant weight were put into Soxhlet extracted using hexane or petroleum ether. After extraction, the sample was removed from the Soxhlet and dried.

$$
\text { Crude lipid }(\%)=\frac{\text { Initial sample weight }(\mathrm{g})-\text { Final sample weight }(\mathrm{g})}{\text { Final sample weight }(\mathrm{g})} \times 100 \%
$$

Ash. The ash was obtained by putting samples into the furnace at $500{ }^{\circ} \mathrm{C}$ for 10 hours. The cooled and stable ash results are then weighed so that the formula can calculate the total ash content:

$$
\text { Ash }(\%)=\frac{W_{1}-W_{2}}{W} \times 100 \%
$$

$\mathrm{W}=$ Sample weight before turn to ashes $(\mathrm{g})$ $\mathrm{W}_{1}=$ Sample weight + porcelain dish after turn to ashes $(\mathrm{g})$

$\mathrm{W}_{2}=$ Weight of an empty porcelain dish (g)

\section{Observed Parameters}

Parameters observed included feed conversion ratio (FCR), protein efficiency ratio (PER), relative growth rate (RGR), and efficiency feed utilization (EFU) based on National Research Council (NRC) (2011), apparent digestibility coefficients for protein (ADCp) based on Fenucci (1981), survival rate (SR) based on Tacon (2002). The equations to analyze the parameters were as follows:
$\mathrm{ADC}_{\mathrm{P}}=100\left(\% \mathrm{Cr}_{2} \mathrm{O}_{3}\right.$ in the feed $/ \%$ $\mathrm{Cr}_{2} \mathrm{O}_{3}$ in the feces) $\mathrm{x}(\%$ protein in the feces $/ \%$ protein in the feed)

$\mathrm{EFU}=100$ (final weight-initial weight/ the amount of feed consumed)

$\mathrm{RGR}=100\left(\mathrm{~W}_{\mathrm{t}}-\mathrm{W}_{\mathrm{o}}\right) /\left(\mathrm{W}_{\mathrm{o}} \times \mathrm{T}\right)$; where $\mathrm{W}_{\mathrm{o}}$ and $\mathrm{W}_{\mathrm{t}}$ are the initial and final weight, respectively, and $\mathrm{T}$ is the number of days in the feeding period $\mathrm{FCR}=100$ [feed intake $(\mathrm{g}) /$ weight gain $(\mathrm{g})]$

PER $=100$ [weight gain $(\mathrm{g}) /$ protein intake $(\mathrm{g})]$

$\mathrm{SR}=100$ (final count/initial count)

\section{Data Analysis}

The impacts of yeast (S. cerevisiae) on experimental parameters were identified using analysis of variance (ANOVA). Suppose the treatments were significant $(P<0.05)$ or highly significant $(P<0.01)$, and then applied the Duncan's multiple range test. The optimum dosage of S. cerevisiae in the feed was analyzed using the polynomial orthogonal test in SAS (version 9) and Maple (version 12). 


\section{RESULTS}

The proximate analysis (Table 1) indicated that the average percentage of raw protein was $30.27 \pm 0.28 \%$, while the average percentage of raw fat was $8.25 \pm 0.24 \%$. The values of ADCp, EFU, PER, RGR, and SR of Sangkuriang catfish fingerlings, which were given yeast ( $S$. cerevisiae) enhanced feed, treatments B, C, D, and E were higher than that without yeast (S. cerevisiae) enhanced feed, treatment A. The yeast $(S$. cerevisiae) enhanced feed significantly affected $(P<0.05)$ on ADCp, EFU, PER, and RGR; however, it did not affect significantly $(P>0.05)$ on SR Sangkuriang catfish fingerlings (Table 2).

Table 1

The results of proximate analysis of test feed

\begin{tabular}{lrrrrc}
\hline \multirow{2}{*}{ Proximate analysis } & \multicolumn{5}{c}{ Diets } \\
\cline { 2 - 5 } & \multicolumn{1}{c}{$\mathrm{A}$} & $\mathrm{B}$ & $\mathrm{C}$ & $\mathrm{D}$ & $\mathrm{E}$ \\
\hline Moisture (\%) & $6.98 \pm 0.12^{\mathrm{a}}$ & $7.18 \pm 0.11^{\mathrm{a}}$ & $6.78 \pm 0.21^{\mathrm{a}}$ & $7.03 \pm 0.15^{\mathrm{a}}$ & $6.88 \pm 0.10^{\mathrm{a}}$ \\
Crude protein (\%) & $30.35 \pm 0.34^{\mathrm{a}}$ & $30.28 \pm 0.36^{\mathrm{a}}$ & $30.18 \pm 0.23^{\mathrm{a}}$ & $30.39 \pm 0.21^{\mathrm{a}}$ & $30.16 \pm 0.35^{\mathrm{a}}$ \\
Crude lipid (\%) & $8.21 \pm 0.15^{\mathrm{a}}$ & $8.34 \pm 0.12^{\mathrm{a}}$ & $8.20 \pm 0.11^{\mathrm{a}}$ & $8.29 \pm 0.20^{\mathrm{a}}$ & $8.21 \pm 0.24^{\mathrm{a}}$ \\
Ash (\%) & $10.23 \pm 0.25^{\mathrm{a}}$ & $10.31 \pm 0.20^{\mathrm{a}}$ & $10.73 \pm 0.12^{\mathrm{a}}$ & $10.28 \pm 0.22^{\mathrm{a}}$ & $10.13 \pm 0.24^{\mathrm{a}}$ \\
Energy (kJ/g) & $8.76 \pm 0.001^{\mathrm{a}}$ & $8.85 \pm 0.001^{\mathrm{a}}$ & $8.84 \pm 0.001^{\mathrm{a}}$ & $8.70 \pm 0.002^{\mathrm{a}}$ & $8.83 \pm 0.003^{\mathrm{a}}$ \\
\hline
\end{tabular}

Note. Mean values $\pm \mathrm{SD}$ with different superscript indicated a significant difference $(P<0.05)$

The proximate analysis performed at the Laboratory of Animal Feed, Faculty of Animal Sciences and Agriculture, Diponegoro University

Table 2

Growth performance of Sangkuriang catfish fingerlings fed yeast enriched feed

\begin{tabular}{lccccc}
\hline Parameters & \multicolumn{5}{c}{ Treatments } \\
\cline { 2 - 6 } & A & B & C & D & E \\
\hline ADC $_{\mathrm{P}}(\%)$ & $64.14 \pm 0.22^{\mathrm{e}}$ & $78.89 \pm 0.29^{\mathrm{b}}$ & $85.12 \pm 0.25^{\mathrm{a}}$ & $73.34 \pm 0.21^{\mathrm{d}}$ & $68.23 \pm 0.20^{\mathrm{c}}$ \\
EFU (\%) & $63.26 \pm 0.32^{\mathrm{e}}$ & $75.03 \pm 0.36^{\mathrm{b}}$ & $83.29 \pm 0.32^{\mathrm{a}}$ & $72.42 \pm 0.37^{\mathrm{d}}$ & $66.25 \pm 0.32^{\mathrm{c}}$ \\
PER & $2.05 \pm 0.24^{\mathrm{e}}$ & $3.58 \pm 0.22^{\mathrm{b}}$ & $4.63 \pm 0.23^{\mathrm{a}}$ & $3.23 \pm 0.24^{\mathrm{d}}$ & $2.96 \pm 0.22^{\mathrm{c}}$ \\
RGR (\%/day) & $2.41 \pm 0.15^{\mathrm{c}}$ & $3.72 \pm 0.26^{\mathrm{c}}$ & $4.58 \pm 0.25^{\mathrm{a}}$ & $3.12 \pm 0.26^{\mathrm{b}}$ & $2.88 \pm 0.27^{\mathrm{b}}$ \\
SR (\%) & $83.33 \pm 2.57^{\mathrm{a}}$ & $93.33 \pm 2.48^{\mathrm{a}}$ & $100 \pm 0.00^{\mathrm{a}}$ & $93.33 \pm 2.65^{\mathrm{a}}$ & $83.33 \pm 2.53^{\mathrm{a}}$ \\
\hline
\end{tabular}

Note. Mean values $\pm \mathrm{SD}$ in different superscript indicated a significant difference $(P<0.05)$ 
The results of the polynomial orthogonal test showed that the relation of yeast $(S$. cerevisiae) in the feed and ADCphas a quadratic pattern, $\mathrm{Y}=-0.4582 \mathrm{x}^{2}+5.5858 \mathrm{x}+65.171$, 0.857 . The optimum dosage of $6.10 \% / \mathrm{kg}$ feed created a maximum value of ADCp as high as $85.73 \%$ (Figure 1). The relation of yeast
(S. cerevisiae) in the feed and EFU was also in the quadratic form, $\mathrm{Y}=-0.4366 \times 2+$ $5.3514 \mathrm{x}+63.517, R^{2}=0.882$, with the optimum dosage of $6.12 \% / \mathrm{kg}$ feed that generated a maximum value of EFU as much as $79.72 \%$ (Figure 2).

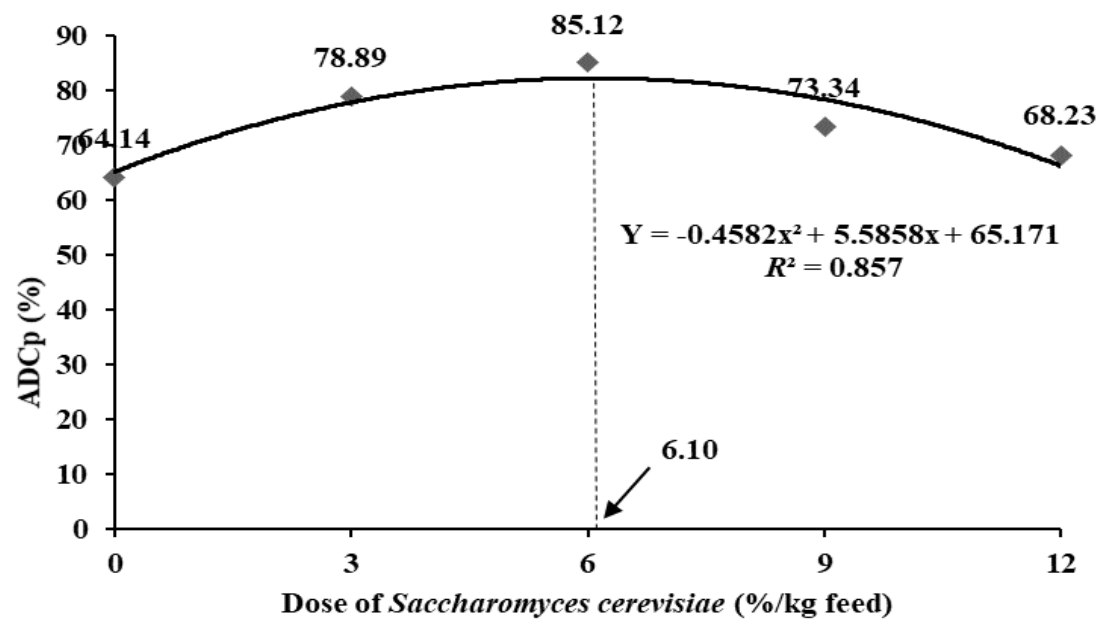

Figure 1. The relation of yeast (Saccharomyces cerevisiae) in the feed and ADCp

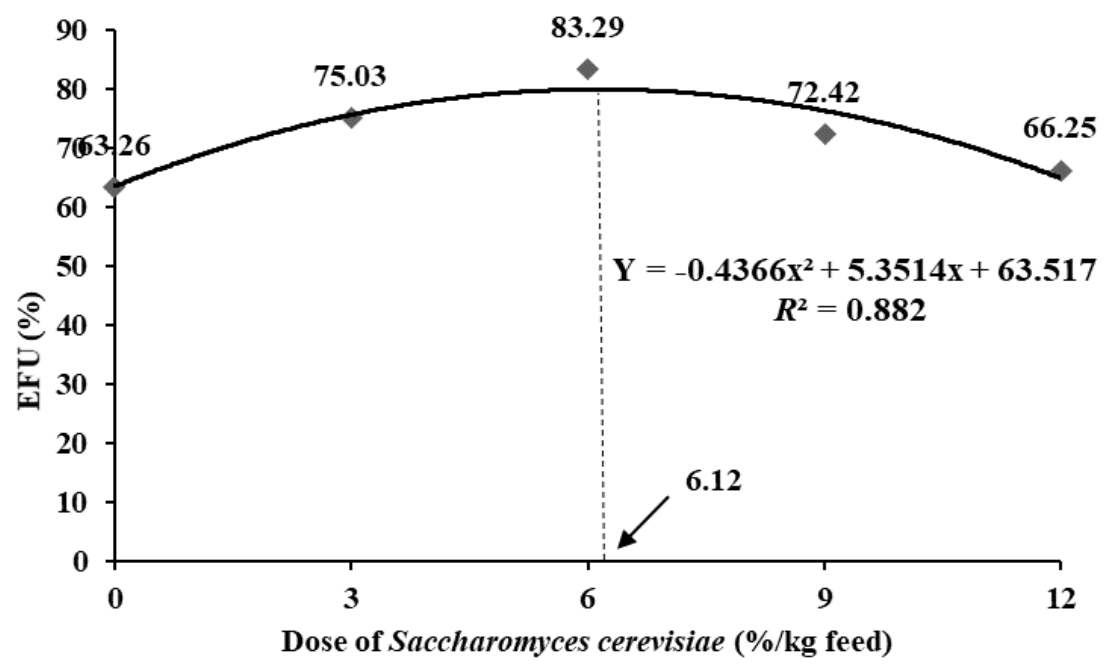

Figure 2. The relation of yeast (Saccharomyces cerevisiae) in the feed and EFU 
The relation of yeast (S. cerevisiae) in the maximum value of PER (4.12\%/day) was feed and PER were in the quadratic equation, obtained from the optimum dosage of $\mathrm{Y}=-0.048 \mathrm{x}^{2}+0.6252 \mathrm{x}+2.1317, R^{2}=0.801 . \quad 6.13 \% / \mathrm{kg}$ feed (Figure 4). Water quality Themaximum value of PER(4.17) was obtained for Sangkuriang catfish cultivation during from the optimum dosage of $6.51 \% / \mathrm{kg}$ feed research was displayed in Table 3 . The water (Figure 3). The relation of yeast (S. cerevisiae) in quality was still in a viable condition for the feed and RGR has quadratic pattern, $\mathrm{Y}=$ Sangkuriang catfish cultivation. $-0.043 \mathrm{x}^{2}+0.5275 \mathrm{x}+2.4997, R^{2}=0.7512$. The

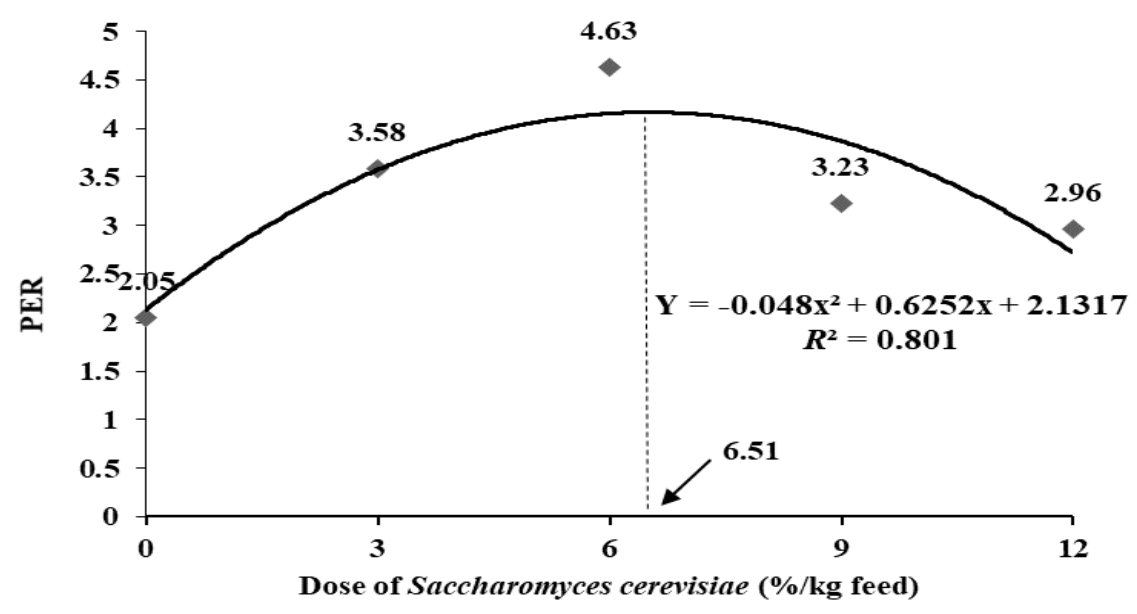

Figure 3. The relation of yeast (Saccharomyces cerevisiae) in the feed and PER

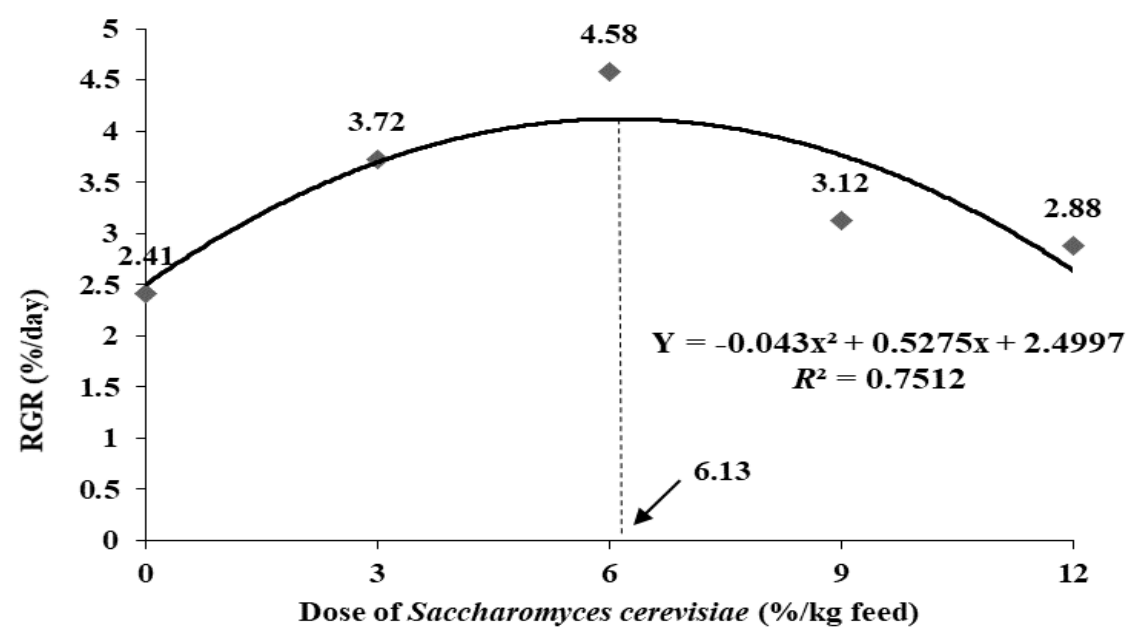

Figure 4. The relation of yeast (Saccharomyces cerevisiae) in the feed and RGR 
Table 3

Water quality for Sangkuriang catfish cultivation during research

\begin{tabular}{lcccc}
\hline \multirow{2}{*}{ Treatment } & \multicolumn{4}{c}{ Water Quality } \\
\cline { 2 - 5 } & Temperature $\left({ }^{\circ} \mathrm{C}\right)$ & $\mathrm{pH}$ & $\mathrm{DO}(\mathrm{mg} / \mathrm{l})$ & $\mathrm{NH}_{3}(\%)$ \\
\hline $\mathrm{A}$ & $26-30$ & $7.26-7.48$ & $5.01-5.78$ & $0.002-0.002$ \\
$\mathrm{~B}$ & $26-30$ & $7.31-7.52$ & $5.23-5.64$ & $0.002-0.002$ \\
$\mathrm{C}$ & $26-30$ & $7.29-7.53$ & $5.12-5.69$ & $0.002-0.002$ \\
$\mathrm{D}$ & $26-30$ & $7.32-7.47$ & $5.17-5.76$ & $0.002-0.002$ \\
Feasibility & $14-38^{*}$ & $6.50-8.5^{*}$ & $>2^{*}$ & $<0.1^{*}$ \\
\hline
\end{tabular}

Note. DO = Dissolved oxygen; $\mathrm{NH}_{3}=$ Ammonia; $*$ Data from the reference $($ Boyd, 2003)

\section{DISCUSSION}

Sangkuriang catfish fingerlings that were fed with the yeast $S$. cerevisiae enhanced feed (treatments B, C, D, and E) had a greater value of ADCp than that without the enrichment of yeast $S$. cerevisiae (A). It was indicated that the enrichment feed with $S$. cerevisiae could produce the digestive enzyme in the fish digestivetract(Welkeretal., 2012). Thehighest value of ADCp (85.12\%) was found in the catfish fed with $S$. cerevisiae enhanced feed with the dosage of $6 \% / \mathrm{kg}(\mathrm{C})$ and followed by the values of $78.89 \%, 73.34 \%, 68.23 \%$, and $64.14 \%$ for B (3\%), D (9\%), E (12\%), and $\mathrm{A}(0 \%)$. The highest value of ADCp in the catfish fed as in treatment $\mathrm{C}(6 \%)$ suggested that the dosage of yeast $(S$. cerevisiae) at $6 \%$ was the right amount of yeast addition to boosting digestive enzyme activities increased protein digestion optimally. In comparison, the dosage other than $6 \%$ resulted in not maximum enzyme activities. The same result was obtained in the Barbonymus gonionotus (Rachmawati et al., 2019a).
The yeast ( $S$. cerevisiae) enhanced feed at the various dosages exhibited significant impacts $(P<0.05)$ on EFU of Sangkuriang catfish fingerlings. It was suggested that the yeast ( $S$. cerevisiae) supplementation in the feed could improve feed absorption; therefore, it increased feed efficiency utilization as the findings of the research by de Azevedo et al. (2016). Sangkuriang catfish fingerlings fed without the enhancement of S. cerevisiae (treatment A) has the lowest value of EFU $63.26 \%$ compared to the catfish fed with the enhancement of $S$. cerevisiae (treatments $\mathrm{B}, \mathrm{C}, \mathrm{D}$, and $\mathrm{E}$ ) with the values of $75.03 \%, 83.29 \%, 72.42 \%$, and $66.25 \%$ respectively. It was suspected that the absence of $S$. cerevisiae in the feed caused no enzyme activity in the digestive tract of the fish. Otherwise, the availability of $S$. cerevisiae in the feed could break down nutrients to easily be absorbed, so it could boost feed efficiency, as reported by Welker et al. (2012). It was suspected that yeast also raises enzymes activity in the digestive tract, such as peptidase, protease, and amylase. 
According to the study by Tewary and Patra (2011), the yeast (S. cerevisiae) in the feed increased enzymes activity, such as peptidase, protease, and amylase in the digestive tract. Hence, it improved the decomposition of complex nutrients into simpler nutrients; in turn, it made absorption easier yeast can increase enzymes activity, such as peptidase, protease, and amylase in the digestive tract. As a result, the enzymes could decompose nutrients into a more straightforward form; therefore, the fish would easily absorb the nutrients (Tewary \& Patra, 2011). According to Hurriyani (2017), the enrichment of yeast (S. cerevisiae) could improve feed digestion. Saccharomyces cerevisiae was known to produce vitamin B complex, especially biotin and vitamin B12 required by the fish digestion system. In addition, the content of peptides in the yeast plays an essential role in enzymatic digestion so that the fish can digest more efficiently. Similar results were reported by Rachmawati et al. (2019a) in the Barbonymus gonionotus and Abdel-Tawwab et al. (2010) in the Sarotherodon galilaeus.

The value of PER in the Sangkuriang catfish fingerlings fed with the yeast $(S$. cerevisiae), as in the treatments $(\mathrm{B}, \mathrm{C}$, $\mathrm{D}$, and $\mathrm{E}$ ), was higher than that without the yeast, as in treatment A. According to Tovar et al. (2002), the existence in the feed could boost protein digestion that supported an increased protein efficiency ratio. This finding was shown in Table 1 that explained the fish fed with the yeast (S. cerevisiae) enhanced feed has a higher value of ADCp compared to the fish fed without additional yeast in the feed. The fish fed with the additional $S$. cerevisiae dosage of $6 \%$ (C) generated the fish to efficiently consume the highest PER, which meant feed with additional yeast. In turn, it could hike protein retention to boost the protein efficiency ratio; however, the higher the yeast dosage caused the protein efficiency ratio to decrease. The findings were in line with Hurriyani's (2017) research that discovered that the additional yeast in the feed increased feed digestion and protein digestibility, resulting in more significant growth and feed efficiency. The level of protein efficiency ratio was also related to the size of the fish and feeding. The same results were found in the Barbonymus gonionotus (Rachmawati et al., 2019a) and Oreochromis niloticus (Abdel-Tawwab et al., 2008).

The yeast ( $S$. cerevisiae) enhanced feed influenced significantly $(P<0.05)$ on RGR Sangkuriang catfish fingerlings. It was suggested that $S$. cerevisiae contains nucleotides, significantly affecting the relative growth rate. The findings were supported by Manoppo and Kolopita's (2016) findings. They discovered that the additional yeast could hike growth because S. cerevisiae contains nucleotide in wet purine and pyrimidine as much as $0,9 \%$. The increasing growth by adding yeast in the feed happened because the nucleotide in the yeast could increase fish appetite to feed; therefore, the feed absorption would increase. The highest value of RGR was $4.58 \%$ /day, which was obtained at the dosage of $6 \%$ S. cerevisiae, as in treatment 
C. The result indicated that the dosage was just the right amount to optimize fish growth. According to Mohammadi et al. (2016), yeast stuck on the surface of the intestine and triggered amylase secretion and hiked digestive enzymes activity; therefore, it increased nutrient digestion. The additional yeast also improved the feeding pattern, boosting growth, and feed efficiency.

The yeast (S. cerevisiae) enrichment in the feed insignificantly influenced $(P<0.05)$ on SR of Sangkuriang catfish fingerlings. The survival rate of Sangkuriang catfish fingerlings in the research ranged from $83.33 \%$ to $100 \%$. A reasonable survival rate indicated that the additional yeast $(S$. cerevisiae) in the feed at the dosages of 0 , $3,6,9$, and $12 \%$ did not cause mortality of the fish. The survival rate of Sangkuriang catfish is the percentage of surviving fish at the end study compared to the number of fish at the start of rearing. Therefore, the survival rate can be used to gauge the tolerance level and ability of the fish to survive. In addition, the survival rate was affected by abiotic factors, such as the ability to adjust to the environment, treatment, stocking density, competitors, diseases, age, and predators (Tacon et al., 2002).

\section{CONCLUSION}

Supplementing yeast (Saccharomyces cerevisiae) in the commercial feed could increase feed efficiency and growth in Sangkuriang catfish fingerlings. However, it did not affect the survival rate of Sangkuriang catfish fingerlings. The optimum dosages of the yeast (S. cerevisiae) in the commercial feed for ADCp, EFU, PER, and RGR ranged from $6.10 \%$ to $6.51 \% / \mathrm{kg}$ feed.

\section{ACKNOWLEDGMENTS}

The author thanked the Ministry of Research, Technology and Higher Education, an applied research grant. However, the completion of the research cannot be accomplished without funding support from the Directorate of Research and Community Service and Directorate of Public Research Enhancement with the letter assignment No: 225-124/ $\mathrm{UN7}$.6.1/ PP/2020 in 2020.

\section{REFERENCES}

Abdel-Tawwab, M., Mousa, M. A. A., \& Mohammed, M. A. (2010). Use of live baker's yeast, Saccharomyces cerevisiae, in practical diet to enhance the growth performance of Galilee tilapia, Sarotherodon galilaeus (L.), and its resistance to environmental copper toxicity. Journal of the World Aquaculture Society, 41(S2), 214-223. https://doi.org/10.1111/j.17497345.2010.00361.x

Abdel-Tawwab, M., Khattab, Y. A. E., Ahmad, M. H., \& Shalaby, A. M. E. (2008). Compensatory growth, feed utilization, whole-body composition and haematological changes in starved juvenile Nile tilapia, Oreochromis niloticus (L.). Journal of Applied Aquaculture, 18(3), 17-36. https://doi. org/10.1300/J028v18n03_02

Al-Refaiee, I. H., Abdulrahman, N. M., \& Mutter, H. A. (2016). Replacement of commercial dry yeast (Saccharomyces cerevisiae) with animal protein concentrate and its effect in some blood parameters for fingerlings common carp 
Cyprinus carpio L. Basrah Journal of Veterinary Research, 15(3), 312-332.

Association of Official Analytical Chemists. (2005). Official methods of analysis of AOAC International (18th ed.). AOAC International.

Boyd, C. E. (2003). Guidelines for aquaculture effluent management at the farm level. Aquaculture, 226(1-4), 101-112. https://doi.org/10.1016/ S0044-8486(03)00471-X

de Azevedo, R.V., Filho, J. C. F., Pereira, S. L., Cardoso, L. D., de Andrade, D. R., \& Júnior, M. V. V. (2016). Dietary mannan oligosaccharide and Bacillus subtilis in diets for Nile tilapia (Oreochromis niloticus). Acta Scietarium Animal Science, 38(4), 347-353. https://doi.org/10.4025/ actascianimsci.v38i4.31360

Fenucci, J. L. (1981). Studies on the nutrition of marine shrimp of the Penaeus [Unpublished Doctoral dissertation]. University of Houston.

Hurriyani, Y. (2017, May 23-24). Evaluasi penambahan ragi roti (Saccharomyces cerevisiae) dalam feed terhadap kinerja pertumbuhan benih ikan Jelawat (Leptobarbus hoevenii) [Evaluation of addition of bread yeast (Saccharomyces cerevisiae) in feed on growth performance of Jelawat fish (Leptobarbus hoevenii)] [Paper presentation]. Prosiding Seminar Nasional Penerapan Ilmu Pengetahuan and Teknologi 2017, Pontianak, Indonesia. https://www. researchgate.net/publication/325013236 EVALUASI_PENAMBAHAN_RAGI_ROTI_ Saccharomyces_cerevisiae_DALAM_PAKAN_ TERHADAP_KINERJA_PERTUMBUHAN_ BENIH_IKAN_JELAWAT_Leptobarbus_ Hoevenii

Manoppo, H., \& Kolopita, M. E. F. (2016). Penggunaan ragi roti (Saccharomyces cerevisiae) sebagai imunostimulan untuk meningkatkan resistensi ikan mas (Cyprinus carpio L.) terhadap infeksi bakteri Aeromonas hydrophila [The use of baker's yeast (Saccharomyces cerevisiae) as immunostimulant to enhance resistance of gold fish, (Cyprinus carpio L.) to Aeromonas hydrophila infection]. Jurnal Budidaya Perairan, 4(3), 37-47. https://doi.org/10.35800/ bdp.4.3.2016.14945

Manurung, U. N., \& Mose, N. I. (2018). Peningkatan pertumbuhan and sintasan hidup ikan bawal (Colossoma macropumum) dengan penambahan ragi roti dalam feed [The improvement growth and survival rate of pomfret fish (Colossoma macropumum) with yeast addition in feed]. Jurnal Saintek Lahan Kering, 1(2), 26-27. https://doi.org/10.32938/slk.v1i2.546

Mohammadi, F., Mousavi, S. M., Zakeri, M., \& Ahmadmoradi, E. (2016). Effect of dietary probiotic, Saccharomyces cerevisiae on growth performance, survival rate and body biochemical composition of three spot cichlid (Cichlasoma trimaculatum). AACL Bioflux, 9(3), 451-457.

National Research Council. (2011). Proteins and amino acids. In Nutrient requirements of fish and shrimp (pp. 57-101). National Academy Press.

Rachmawati, D., \& Samidjan, I. (2018). The effects of papain enzyme supplement in feed on protein digestibility, growth and survival rate in Sangkuriang catfish (Clarias sp.). Omni-Akuatika, 14(2), 91-99. https://doi. org/10.20884/1.oa.2018.14.2.551

Rachmawati, D., Hutabarat, J., Samidjan, I., Herawati, V. E., \& Windarto, S. (2019a). The effects of Saccharomyces cerevisiae-enhanced diet on feed usage efficiency, growth performance and survival rate in Java barb (Barbonymus gonionotus) fingerlings. AACL Bioflux, 12(5), 1841-1849.

Rachmawati, D., Istiyanto, S., Ristiawan, A. N., \& Susilowati T. (2019b). Effects of Sacharomyces cereviceae incorporated diet on growth performance, apparent digestibility coefficient of protein and survival rate of catfish (Pangasius hypothalamus). Aquacultura Indonesiana, 20(1), 8-14. https://doi.org/10.21534/ai.v20i2.140 
Rachmawati, D., Samidjan, I., \& Mel, M. (2017). Effect of phytase on growth performance, feed utilization efficiency and nutrient digestibility in fingerlings of Chanos chanos (Forsskal 1775). Philippine Journal of Science, 146(3), 237-245.

Sitohang, R., Herawati, V., T., \& Lili, W. (2012). Pengaruh pemberian dedak padi hasil fermentasi ragi (Saccharomyces cerevisiae) terhadap pertumbuhan biomassa Daphnia sp. [Effect of yeast fermentation rice bran (Saccharomyces cerevisiae) on the growth of Daphnia sp. biomass]. Jurnal Perikanan and Kelautan, 3(1), 65-72.

Tacon, A. G. J., Cody, J. J., Conquest, L. D., Divakaran, S., Forster, I. P., \& Decamp, O. E. (2002). Effect of culture system on the nutrition and growth performance of Pacific white shrimp Litopenaeus vannamei (Boone) fed different feeds. Aquaculture Nutrition, 8(2), 121-137. https://doi.org/10.1046/j.13652095.2002.00199.x

Tewary, A., \& Patra, B. C. (2011). Oral administration of baker's yeast (Saccharomyces cerevisiae) acts as a growth promoter and immunomodulator in Labeo rohita (Ham.). Journal of Aquaculture Research and Development, 2(1), 1000109. https://doi.org/10.4172/2155-9546.1000109
Tovar, D., Zambonino, J., Cahu, C., Gatesoupe, F. J., Va'zquez-Ju'arez, R., \& Le'sel, R. (2002). Effect of live yeast incorporation in compound diet on digestive enzyme activity in sea bass (Dicentrarchus labrax) larvae. Aquaculture, 204(1-2), 113-123. https://doi.org/10.1016/ S0044-8486(01)00650-0

Vendrell, D., Balcazar, J. L., de Blas, I., Ruiz-Zarzuela, I., Girones, O., \& Muzquiz, J. L. (2008). Protection of rain-bow trout (Oncorhynchus mykiss) from lactococcosis by probiotic bacteria. Comparative Immunology, Microbiology and Infectious Diseases, 31(4), 337-345. https://doi. org/10.1016/j.cimid.2007.04.002

Welker, T. L., Lim, C., Yildirim-Aksoy, M., \& Klesius, P. H. (2012). Effect of short-term feeding duration of diets containing commercial whole-cell yeast or yeast subcomponents on immune function and disease resistance in channel catfish, Ictalurus punctatus. Journal of Animal Physiology and Animal Nutrition, 96(2), 159-171. https://oi. org/10.1111/j.1439-0396.2011.01127.x 